\title{
PELATIHAN KLASIFIKASI BUKU DAN PEMBUATAN KARTU KATALOG BUKU BAGI PETUGAS PERPUSTAKAAN SEKOLAH TINGKAT SEKOLAH DASAR (SD) DI KOTA SINGARAJA
}

\author{
oleh, \\ I Ketut Artana \\ Unit Perpustakaan \\ Universitas Pendidikan Ganesha
}

\begin{abstract}
ABSTRAK
Kegiatan Pengabdian pada Masyarakat (P2M) Undiksha bidang perpustakaan dalam bentuk Pelatihan Klasifikasi Buku dan Pembuatan Kartu Katalog Buku Bagi Petugas Perpustakaan Sekolah Tingkat Sekolah Dasar (SD) di Kota Singaraja bertujuan untuk meningkatkan kemampuan (pengetahuan dan pemahaman) dan keterampilan petugas perpustakaan dilaksanakan pada hari Selasa, 25 September 2012 bertempat di Gedung Perpustakaan Pusat Undiksha dihadiri sebanyak 18 orang tenaga perpustakaan sekolah tingkat Sekolah Dasar di kota Singaraja. Metode kegiatan pelatihan meliputi ceramah, diskusi, tanya jawab, simulasi (peragaan) dan praktik kerja bidang klasifikasi dan katalogisasi buku.Respon peserta pelatihan terhadap kegiatan pelatihan klasifikasi dan katalogisasi buku termasuk kategori positif. Terjadi peningkatan kemampuan (pengetahuan dan pemahaman) dan keterampilan peserta dalam bidang klasifikasi dan katalogisasi buku. Peserta berharap agar kegiatan semacam ini dapat terus dilakukan secara terprogram dalam rangka peningkatan pengelolaan buku guna meningkatkan kunjungan dan pemanfaatan perpustakaan sekolah khususnya di tingkat Sekolah Dasar di kota Singaraja.
\end{abstract}

Kata-kata kunci: pelatihan, klasifikasi, katalog, perpustakaan sekolah

\section{Pendahuluan}

Sebagaimana telah diketahui, bahwa dalam dunia pendidikan, perpustakaan merupakan sarana dan prasarana pendidikan yang memiliki kedudukan strategis, sentral, dan integral. Perpustakaan sekolah yang berada pada satuan pendidikan formal di lingkungan pendidikan dasar dan menengah yang merupakan bagian integral dari kegiatan sekolah yang bersangkutan dan merupakan pusat sumber belajar untuk mendukung terwujudnya tujuan pendidikan sekolah yang bersangkutan, bertujuan menyediakan pusat sumber belajar sehingga dapat membantu pengembangan dan peningkatan minat baca, literasi informasi, bakat serta kemampuan peserta didik. Oleh karena itu, petugas perpustakaan sekolah diharapkan mampu mengelola perpustakaan secara profesional untuk kepentingan para penggunanya. 
Perpustakaan sekolah tingkat Sekolah Dasar (SD) di kota Singaraja pada umumnya menempati ruangan atau gedung tersendiri. Ruang/gedung perpustakaan sekolah dasar dilengkapi dengan sumber daya perpustakaan, diantaranya bahan pustaka (buku), petugas, rak buku, meja baca, dan fasilitas penunjang pengelolaan perpustakaan. Tingkat kunjungan dan pemanfaatan perpustakaan sekolah tingkat Sekolah Dasar (SD) di kota Singaraja cukup rendah dikarenakan buku-buku yang dimiliki belum diolah secara benar dan penataan/pengaturan buku di rak-rak buku cenderung amburadul (tidak teratur). Sedangkan, petugas (pengelola) perpustakaan tingkat Sekolah Dasar (SD) di kota Singaraja adalah para guru yang diberi tugas tambahan oleh Kepala Sekolah sebagai pengelola atau pembina perpustakaan. Para guru yang merangkap sebagai pengelola perpustakaan belum memiliki kualifikasi kompetensi kepustakawanan. Pengolahan buku-buku dilaksanakan secara sederhana dan manual. Dari pemantauan dan wawancara tim pengabdian dari Universitas Pendidikan Ganesha ditemukan ada beberapa hambatan yang dialami petugas perpustakaan tingkat Sekolah Dasar (SD) di kota Singaraja dalam rangka memajukan perpustakaan sekolah yang berkualitas. Hambatan tersebut antara lain: masalah kemampuan dan keterampilan petugas, metode/teknik, sarana dan prasarana, dan masalah ketersediaan anggaran.

Dalam pengolahan (klasifikasi dan katalogisasi) buku-buku dapat dikemukakan bahwa perpustakaan sekolah tingkat Sekolah Dasar (SD) di kota Singaraja belum memiliki alat bantu pengolahan buku, seperti: pedoman klasifikasi persepuluhan Dewey (buku DDC), pedoman tajuk subjek (Subject Heading), dan pedoman katalogisasi. Walaupun begitu pengolahan buku dilakukan secara sederhana, seperti pengelompokkan buku-buku berdasarkan jenis yaitu buku fiksi dan non fiksi, kemudian pemberian nomor klas buku memakai nomor inventaris buku (buku induk) dan bukan nomor klas sistem DDC sesuai aturan baku dalam pengklasifikasian buku. Selanjutnya, buku-buku yang telah diolah secara sederhana belum dibuatkan kartu katalog buku sebagai sarana penelusuran informasi buku. Penataan dan pengaturan buku-buku di rak belum tertata dengan baik.

Kondisi seperti itu menempatkan perpustakaan sebagai pusat sumber informasi kurang diminati untuk dikunjungi oleh para peserta didik. Hal ini tentunya tidak boleh dibiarkan akan tetapi harus ada upaya yang sungguh-sungguh dan berkelanjutan untuk melatih para petugas perpustakaan dalam mengolah buku (klasifikasi dan katalogisasi) 
sehingga buku-buku yang dimiliki dapat diolah secara profesional dan selanjutnya dilayankan dan dimanfaatkan secara optimal oleh para pemustaka.

Berdasarkan pada kondisi di atas, maka kegiatan pengabdian pada masyarakat dalam bentuk pelatihan klasifikasi buku dan pembuatan kartu katalog buku bagi petugas perpustakaan sekolah tingkat SD menjadi penting dan tepat untuk dilaksanakan. Hal ini mengingat pelatihan ini akan dapat memberikan manfaat penting bagi petugas perpustakaan dalam mengolah koleksi buku yang dimilikinya. Melalui pengolahan (klasifikasi dan katalogisasi) buku secara baku dan dikerjakan secara profesional oleh para petugas perpustakaan, maka koleksi buku-buku akan dapat dilayankan dan dimanfaatkan oleh para peserta didik serta harapan untuk mewujudkan siswa (peserta didik) yang cerdas, unggul dan kreatif akan dapat terwujud.

Pembekalan materi ajar yang diikuti dengan pelatihan klasifikasi buku dan pembuatan kartu katalog buku untuk petugas perpustakaan sekolah tingkat Sekolah Dasar (SD) belum pernah dilakukan pada petugas perpustakaan SD di kota Singaraja dan bahkan di Bali. Sedangkan permasalahan pokok yang hendak dicarikan solusi dalam kegiatan pengabdian pada masyarakat ini adalah sebagai berikut. (1) Dalam hal kemampuan (pengetahuan) petugas perpustakaan SD di kota Singaraja dalam melakukan klasifikasi dan katalogisasi buku masih kurang, dan (2) Dalam hal keterampilan (keahlian) petugas perpustakaan SD di kota Singaraja dalam memberikan nomor klas (nomor panggil buku berdasarkan sistem DDC) dan membuat kartu katalog buku (katalog subjek, pengarang, judul) masih kurang. Tujuan utama dari kegiatan pengabdian pada masyarakat ini adalah meningkatkan kemampuan (pengetahuan/wawasan) dan keterampilan petugas perpustakaan sekolah tingkat SD di kota Singaraja dalam mengklasifikasi buku dengan sistem DDC dan pembuatan kartu katalog buku dalam upaya peningkatan kunjungan dan pemanfaatan perpustakaan.

\section{Metode Pelaksanaan Pengabdian}

Materi (bahan dan alat) yang digunakan dalam kegiatan ini antara lain buku pedoman pengklasifikasian buku yaitu DDC (Dewey Decima Classification), Pedoman Katalogisasi Buku, Daftar Tajuk Subjek, Kamus Bahasa, kartu-kartu katalog dari kertas manila, buku dan perlengkapan lainnya. Materi ini dipakai pada saat peserta melakukan 
praktik klasifikasi buku dan pembuatan kartu catalog buku. Beberapa prinsip dasar dalam klasifikasi yang harus diperhatikan oleh petugas perpustakaan yaitu: (1) kecuali kesusasteraan, klasifikasi buku menurut subjeknya kemudian menurut bentuknya, (2) klasifikasilah buku sesuai dengan maksud dan tujuan pengarangnya, (3) klasifikasilah buku pada subjek yang paling spesifik dan bukan pada subjek yang lebih luas, (4) apabila sebuah buku dapat ditempatkan pada dua nomor klasifikasi yang sama tepatnya, maka klasifikasilah pada nomor klas yang paling bermanfaat bagi pemakainya, (5) apabila sebuah buku membahas dua subjek atau lebih yang saling berhubungan, klasifikasilah pada subjek yang paling banyak tekanan/uraiannya, (6) apabila sebuah buku membahas dua subjek atau lebih yang tidak saling berhubungan, maka klasifikasilah pada subjek yang paling banyak diuraikan, bila uraiannya sama banyak, klasifikasilah pada subjek yang lebih dahulu dalam buku tersebut, atau kalau tidak jelas mana yang lebih banyak diuraikan,maka klasifikasilah pada subjek yang disebut terlebih dahulu dalam bagan klasifikasi, (7) bila sebuah buku memuat tiga subjek atau lebih yang semuanya merupakan bagian dari subjek yang lebih luas, hendaknya diklasifikasikan pada subjek yang mencakup semuanya, (8) bila sebuah buku terdiri dari dua subjek yang saling mempengaruhi, maka klasifikasilah pad asubjek yang dipengaruhinya, dan (9) apabila sebuah buku punya subjek yang membahas dua aspek atau lebih dan tidak jelas aspek mana yg diutamakan, maka klasifikasilah pada: pada aspek disiplin yang lebih luas, pada disiplin yang merupakan dasar dara aspek lain.Sedangkan dalam pembuatan kartu katalog buku yang perlu mendapat perhatian yaitu tentang format kartu katalog yaitu: (1) format katalog kartu meliputi : nomor panggil (Call Number/No.Akses), tajuk, dan deskripsi bibliografis. Deskripsi Bibliografis meliputi hal-hal sbb: bidang judul dan pernyataan kepengarangan, judul (utama, anak judul, judul alterntaif, judul paralel), pernyataan kepengarangan (ditulis setelah judul, dipisahkan dengan tanda baca garis miring (/), (2) bidang Edisi, (3) bidang Impresum/ket. Penerbitan (kota/tempat terbit, nama penerbit dan tahun terbit), 4) bidang Kolasi (pernyataan fisik buku : jlh halaman, ket. gambar/ilustrasi, dan ukuran tinggi buku, (5) bidang Seri, (6) bidang Catatan/Anotasi, (7) bidang ISBN (International Standard Book Number), dan (8) bidang Jejakan.

Metode yang dipilih dalam pelaksanaan kegiatan ini adalah pelatihan, yang tahapannya adalah sebagai berikut : 


\section{1) Ceramah dan Diskusi}

Metode ini dimaksudkan untuk memperdalam pengetahuan dan pemahaman petugas perpustakaan sekolah tingkat SD di kota Singaraja tentang peran penting klasifikasi buku dengan sistem DDC dan manfaat kartu katalog buku bagi petugas dan pemustaka. Pemberian informasi/ceramah ini melalui seminar (penyampaian makalah) yang diberikan oleh Ketua Tim Pengabdian pada Masyarakat. Setelah penyampaian materi dilanjutkan dengan tanya jawab dan diskusi.

\section{2) Latihan dan Praktek}

Metode ini dimaksudkan untuk mengimplementasikan teori-teori yang diperoleh melalui penyampaian informasi (seminar), tanya jawab dan diskusi. Mekanisme pelaksanaan, peserta pelatihan secara bersama-sama dalam kerja kelompok membagi diri mengklasifikasi buku dalam berbagai subjek/disiplin ilmu dan membuat kartu katalog buku (katalog judul, katalog pengarang dan katalog subjek). Hasil dari pelatihan berupa produk berupa dokumen tertulis, metode/sistem dan artikel ilmiah berupa daftar klasifikasi buku dan kartu katalog buku di masing-masing sekolah. Pelatihan ini langsung dipandu dan dibimbing oleh pelatih.

Untuk mengetahui keberhasilan kegiatan pengabdian kepada masyarakat, maka dilakukan evaluasi dalam bentuk (1) test teori dan keterampilan klasifikasi buku dan pembuatan kartu katalog buku (subjek, pengarang dan judul), (2) penyebaran kuesioner, (3) observasi, dan (4) interview. Rancangan evaluasi yang digunakan adalah pre-tes dan post test evaluation, seperti ditunjukkan pada gambar di bawah ini.

\begin{tabular}{|l|} 
PRE-TEST \\
Kompetensi \\
Kemampuan
\end{tabular}

Gambar 1. Rancangan Evaluasi

Indikator keberhasilan dari pelaksanaan pengabdian kepada masyarakat tentang penyelenggaraan program pelatihan klasifikasi buku dan pembuatan kartu katalog buku bagi petugas perpustakaan sekolah tingkat SD di kota Singaraja adalah sebagai berikut. (1) Kehadiran peserta lebih besar dari 90\% dari jumlah yang diundang; (2) Rerata skor 
test teori dan praktek mengklasifikasi buku dan membuat kartu katalog buku, hasil peserta minimal 85, dan (3) Respon pemustaka terhadap pelaksanaan pelatihan berkategori baik. Setelah kegiatan pengabdian ini selesai maka diadakan evaluasi atas hasil kegiatan berupa aplikasi terhadap klasifikasi dan katalogisasi buku. Aktivitas ini dipantau dan dilihat perkembangannya apakah ada perubahan atau perkembangan ke arah positif setelah adanya pelatihan klasifikasi dan katalogisasi buku Perpustakaan. Hal ini dimaksudkan untuk melihat efektivitas pelatihan ini dalam upaya peningkatan pengolahan koleksi perpustakaan.

\section{Hasil dan Pembahasan}

Kegiatan pengabdian pada masyarakat bidang perpustakaan tahun 2012 dalam bentuk pelatihan klasifikasi buku dan pembuatan kartu katalog buku bagi para pengelola perpustakaan sekolah tingkat Sekolah Dasar di kota Singaraja dilaksanakan selama 1 (satu) hari yaitu hari Selasa, 25 September 2012, bertempat di Gedung Perpustakaan Pusat Undiksha lantai 2. Peserta pelatihan klasifikasi dan katalogisasi buku adalah para pengelola perpustakaan sekolah tingkat SD yang ada di kota Singaraja. Dari 20 orang yang diundang yang berkesempatan mengikuti kegiatan sebanyak 18 orang (90\%). 2 (dua) orang yang tidak hadir karena ada kesibukan di masing-masing sekolah. Pelaksanaan kegiatannya yaitu Pemberian informasi melalui seminar yang diberikan langsung oleh nara sumber yaitu Ketua Pelaksana (Kepala Perpustakaan Undiksha), Drs. I Ketut Artana,S.Sos. Pemberian materi pelatihan dengan metode ceramah, peragaan, tanya jawab dan diskusi. Setelah itu dilanjutkan dengan pelatihan (praktik membuat atau memberi nomor klas buku berdasarkan DDC dan membuat kartu katalog buku). Dalam pelaksanaannya secara bersama-sama dalam bentuk kerja kelompok menyelesaikan soal-soal dan tugas. Pelatihan langsung dibimbing oleh nara sumber.

Kegiatan ini berlangsung lancar, sukses dan cukup berhasil meningkatkan pengetahuan/kemampuan dan keterampilan peserta, terlihat dari aktivitas peserta (petugas perpustakaan SD) mengikuti kegiatan latihan tergolong aktif yakni dalam kegiatan diskusi, peserta secara aktif bertanya dan berusaha memecahkan permasalahan yang dihadapi terkait dengan pengolahan buku-buku (klasifikasi dan katalogisasi buku) yang dibahas ketika pelatihan. Tugas-tugas yang diberikan terkait dengan klasifikasi buku dan pembuatan kartu katalog buku dikerjakan secara berkelompok dan hasilnya dipresentasikan secara bergantian ketika pelatihan. Sebagian besar waktu dalam 
pertemuan dengan peserta pelatihan dihabiskan untuk diskusi pemahaman dalam memberikan nomor klas buku yang tepat sesuai sistem DDC dan membuat kartu katalog buku, seperti katalog judul, katalog pengarang dan katalog subjek. Pelaksanaan program pelatihan cukup optimal, tanggapan peserta terhadap kegiatan latihan cukup baik. Keberlanjutan kegiatan P2M ini diharapkan oleh para peserta pelatihan (petugas perpustakaan SD). Tanggapan peserta pelatihan terhadap kegiatan P2M ini melalui wawancara dan angket adalah positif.

\section{Penutup}

Sebagai kesimpulan dapat disampaikan bahwa pelaksanaan P2M bidang perpustakaan khususnya pada materi klasifikasi dan katalogisasi buku telah berhasil dalam hal; (a) peningkatan pengetahuan dan pemahaman petugas perpustakaan SD di kota Singaraja tentang klasifikasi buku dan katalogisasi buku, (b) peningkatan keterampilan petugas perpustakaan SD di kota Singaraja dalam hal memberi nomor panggil/nomor akses buku sesuai DDC dan membuat kartu katalog buku (katalog judul, pengarang dan subjek).

\section{DAFTAR PUSTAKA}

Basuki, Sulistyo. 1994. Pengantar Ilmu Perpustakaan. Jakarta : Gramedia Pustaka Utama

PerpusnasRI. 2009. Undang-Undang Nomor 43 tentang Perpustakaan. Jakarta : Perpustakaan Nasional RI

Soeatminah, 1992. Perpustakaan, Kepustakawanan dan Pustakawan. Yogyakarta : Kanisius

Suhendar, Yaya. 2007. Pedoman Katalogisasi : Cara Mudah Membuat Katalog Perpustakaan. Jakarta : Kencana Prenada Media Group 